\title{
DWARFS IN HISTORY
}

\section{Dr Samanthi Cooray¹, Dr Noel P Somasundaram²}

1. Consultant Endocrinologist, BH Kalutara

2. Consultant Endocrinologist, National Hospital of Sri Lanka

I recently encountered this very interesting gentleman (figure 1) during my travel to Europe.I thought it worthwhile to introduce him to the endocrinology arena so that due appreciation is given to him from that point of view.

\section{Figure 1}

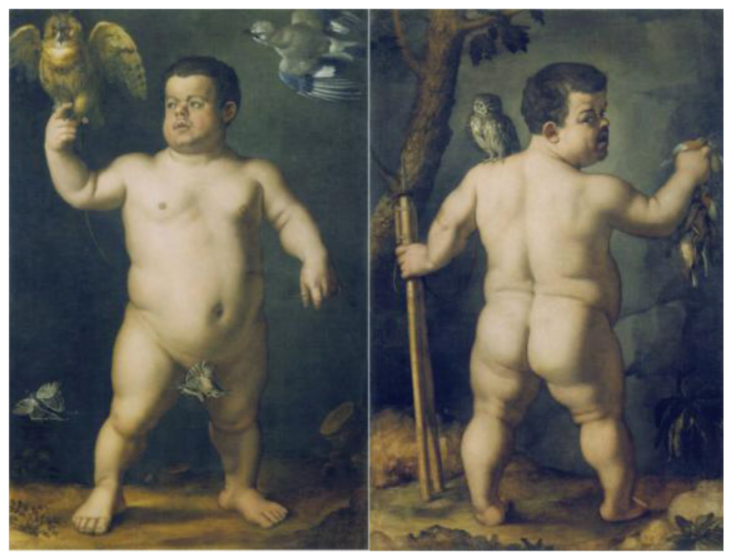

He initially caught my eye as a painting of an adult man stuck in a child-like body. This painting is unique for itsfront and back portraying making it a three-dimensional art form. He was not a beautiful creature. But he stood proud in his-self, displaying his fascinating body. He was cherubic with a protruding abdomen which was in part due to the exaggerated lumbar lordosis. The most striking feature about him was his stature. He was short with a standing height markedly below the $3^{\text {rd }}$ percentile for his age and sex. But in contrast his sitting height was within normal limits reflecting a normal trunk length. He also had disproportionately short limbs and short stubby digits. His chest was flattened antero-posteriorly and there were redundant skin folds in the limbs.
I was told that he was a distinguished member of the court of the grand duke of Tuscany. Although he was known for his superior intellect, he was in the business of entertainment and he did have a 'comical' appearance. This was due to a combination of an oversized head with frontal bossing, mid facial hypoplasia, flattened nasal bridge and a prominent mandible. In fact his main role in the court had been as a jester,but later he had even been the advisor of the duke given his wisdom in court matters and ability to charm the duke.

I will now introduce the individual of interest, who is the dwarf Braccio di Bartolo- better known as Morgante, named ironically in reference to the theatre work by Luigi PulciMorgante, whose protagonist Morgante was a giant. Morgantewas the favourite court dwarf and prized entertainer of Cosimo I de Medici who was the grand duke of Tuscany, well remembered for creating political stability in the $16^{\text {th }}$ century Florence.This dwarf was 'clever, learned and kind' according to Giorgio Vasari, the art historian and had a distinguished presence in the Medici court.

Morganteis portrayed in 3 places in the city of Florence where I met him as a tourist. He was depicted in a small fountain by Giambologna in the Bargello, another small fountain (called Bacchino) by Cioli in the Boboli Gardens, and the double painting by Bronzino in the Uffizi. In all three he is naked and this might be a reflection of the artistic beauty the duke saw in his dwarf's disproportionate body, although the animals and 
birds with the dwarf pointsto a derogatory nature.

Figure 2

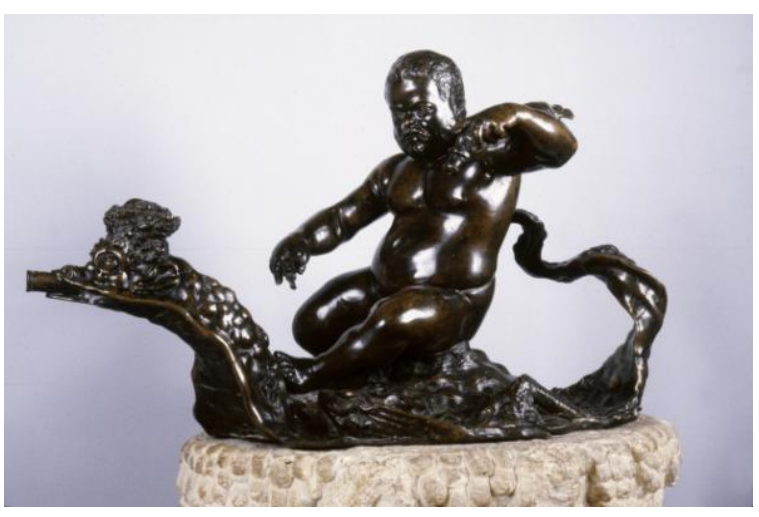

In Giambologna's fountain (figure 2) Morgante sits on a dragon with his hand raised to still the waters imitating Neptune, the Roman god of the ocean.

\section{Figure 3}

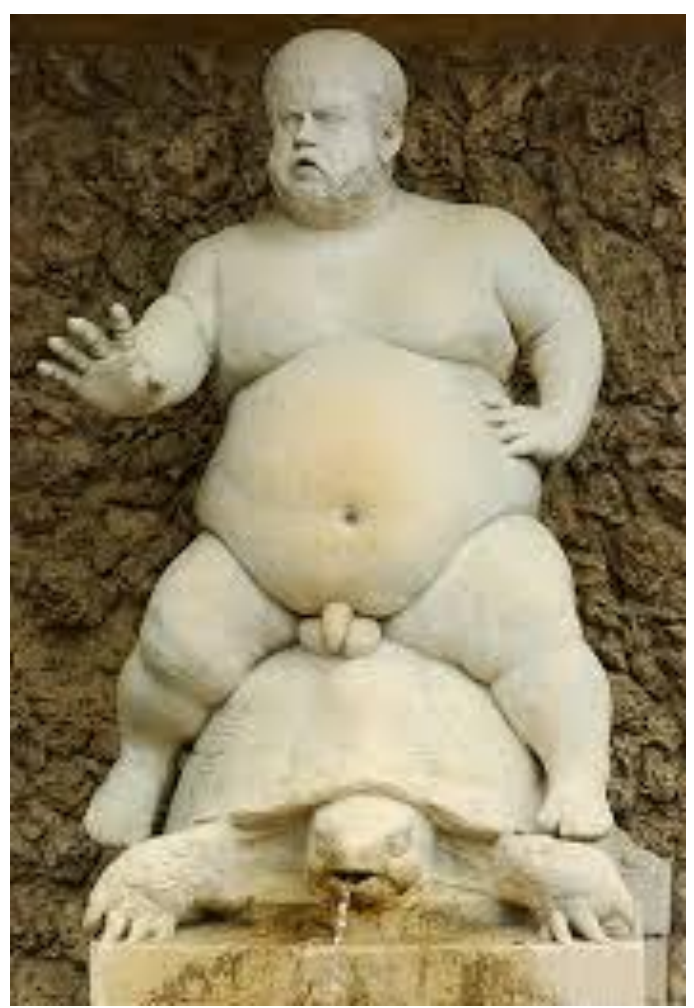

In this marble fountain (figure 3) by Valerio Cioli, Morgante is seen riding the tortoise with his right hand in a similar position to that of Marcus Aurelius' equestrian statue in Rome. The tortoise itself is a symbol of Cosimo, chosen to illustrate one of his mottos: Festinalente (more haste, less speed).Here again the features of achondroplasia is made prominent and the normal genitals are also in keeping with the condition.

Bronzino's painting (figure 1) reveals him completely naked and shows both anterior and posterior views of the plump moustachioed dwarf who is 'bird hunting'. Here he holds an owl tied with a string. For nearly 5 centuries the dwarf's nakedness had been obscured by vines and grapes, butin 2010 the painting has been restored back to its true form at Florence's Uffizi museum.

\section{Discussion}

Dwarfs in the Renaissance period did not have an easy life. From an early age they were subjected to ridicule and abuse, and were often sold to circuses where they had to perform degrading acts. Some were sold off to the courts of royalty for entertainment, where a few even succeeded to become advisors of their lords, as in the case of dwarf Morgante.

Although the artistic and historical aspects of these Renaissance pieces were fascinating, I being a clinician and an endocrinologist was drawn to dwarf Morgante mainly due to short stature, rhizomelicshortening of the long bones and craniofacial abnormalities, which made me make a diagnosis of Achondroplasia.Achondroplasia, which is the commonest form of dwarfism is characterised by short limbs, with the patients' sitting height in the normal range. In the affected individuals the arms and thighs more are severely involved than the forearms, legs, hands, and feet (3).

Achondroplasia has been described in art form as far back as the Egyptian civilization. Egyptian art 
depicts dwarfs as personal attendants, animal tenders, jewellers and entertainers as well as highranking individuals in the societyclosely related to the king. The well -known oneswere Seneb, Pereniankh, Khnumhotpe, and Djeder. There are also depictions of two dwarf gods, Ptah and Besin Egyptian art (1).Although short and unattractive, due to their normal intellect and comical appearance dwarfs have become important figures in all era of history.

Achndroplasia is transmitted as an autosomal dominant trait due to a single gene mapped to the short arm of the fourth chromosome (band 4 p16.3) (2). But $80 \%$ of the cases are sporadic.The heterozygous state is affected and the homozygous is ordinarily fatal in the first few months of life. The molecular defect is in the fibroblast growth factors (FGF), whichare structurally related proteins associated with cell growth, migration, wound healing, and angiogenesis. At the cellular level, their function is mediated by transmembrane tyrosine kinase receptors, known as fibroblast growth factor receptors (FGFR) (4).The gain of function mutation in FGFR3 of which the primary function is to limit osteogenesis causes increased signal transduction leading to the primary defect in achondroplasia, which is abnormal endochondral ossification. Periosteal and intramembranous ossification is normal. The end results are short and broad tubular bones.

Current therapeutic strategies focus on reducing the signal transductions from the mutant FGFR3.Therapies directly targeting FGFR3, such as kinase inhibitors and neutralizing antibodies are still in the experimental stage.C- natriuretic peptide (CNP) which antagonizes the downstream effects of the aberrant FGFR3 signal, is another medication which is currently undergoing early Phase II clinical trials, that has been shown to normalize bone growth in mouse models of achondroplasia (5).

\section{REFERENCES}

1. Kozma, Chahira. "Dwarfs in ancient Egypt". American Journal of Medical Genetics(2005-12-27); 140A(4): 303-311

2. Baitner AC, Maurer SG, Gruen MB, Di Cesare PE. The genetic basis of the osteochondrodysplasias. J Pediatr Orthop. Sep-Oct 2000; 20(5):594-605.

3. Laederich MB, Horton WA. Achondroplasia: pathogenesis and implications for future treatment. Curr Opin Pediatr. Aug 2010; 22(4):516-23

4. Wang Q, Green RP, Zhao G, Ornitz DM. Differential regulation of endochondral bone growth and joint development by FGFR1 and FGFR3 tyrosine kinase domains. Development. Oct 2001;128(19):3867-76.

5. Lorget F, Kaci N, Peng J, et al. Evaluation of the therapeutic potential of a CNP analog in a Fgfr3 mouse model recapitulating achondroplasia. Am J Hum Genet. 2012;91(6):1108-1114 